\title{
BCL-6 Oncoprotein in Breast Cancer: Loss of Expression in Disease Progression
}

\author{
António E. Pinto ${ }^{a}$ Saudade André $^{a}$ Giovani Silva $^{c}$ Sara Vieira ${ }^{b}$ Ana C. Santos ${ }^{d}$ \\ Sérgio Dias ${ }^{b}$ Jorge Soares ${ }^{a}$ \\ ${ }^{a}$ Serviço de Anatomia Patológica e ${ }^{b}$ Centro de Investigação de Patobiologia Molecular (CIPM) do Instituto \\ Português de Oncologia de Lisboa, E.P.E., ' Departamento de Matemática do Instituto Superior Técnico de Lisboa, \\ and ${ }^{\mathrm{d} I n s t i t u t o}$ de Anatomia Patológica, Faculdade de Medicina, Universidade de Lisboa, Lisboa, Portugal
}

\section{Key Words}

Breast cancer $\cdot$ BCL-6 oncoprotein •

Immunohistochemistry $\cdot$ RT-PCR $\cdot$ Prognosis

\begin{abstract}
Objective: To investigate the biological role of $\mathrm{BCL}-6$ oncoprotein in breast cancer disease progression (recurrence and metastasis). Methods: The series consisted of 93 consecutive female patients with primary breast cancer and median follow-up of 10 years. BCL- 6 expression was assessed in vivo by immunohistochemistry and real-time PCR. Breast cancer cell lines and some metastasis-related genes (CXCR4, Itg $\beta-3$ and FLT-1) were also analysed by molecular techniques. Prognostic evaluation was performed by fitting a multivariate Cox regression model. Results: $\mathrm{BCL}-6$ immunoexpression was positive in 22 (23.7\%) tumours and negative in 71 (76.3\%). All axillary lymph node metastases of 47 node-positive patients were negative, including 12 cases showing BCL-6-positive primary tumours. Likewise, in 9 recurrence cases, BCL- 6 expression was similar or decreased compared with primary tumours. No correlation between immunoexpression and gene expression of $\mathrm{BCL}-6$ was observed. BCL- 6 was significantly reduced both in derived metastases of a breast cancer cell line (M435) and when the latter was treated with a demethylation agent (5-azacytidine). However, BCL-6-transfected breast cancer cell lines expressed significantly higher
\end{abstract}

levels of CXCR4, Itg $\beta-3$ and FLT-1. Co-expression of the 4 genes was found in 4 of 17 tumours evaluated, but lacking prognostic significance. $\mathrm{BCL}-6$ oncoprotein revealed no significant influence on outcome. Conclusion: The results strongly suggest the loss of BCL- 6 expression in breast cancer progression, which might be related with methylation status alterations of still unknown partner gene(s).

Copyright $\odot 2009$ S. Karger AG, Basel

\section{Introduction}

B cell lymphoma gene 6 (BCL-6) oncoprotein is a 95$\mathrm{kD}$ nuclear phosphoprotein belonging to the $\mathrm{BTB} / \mathrm{POZ}$ zinc finger family of transcription factors, which is mainly expressed in normal lymph node germinal centre B cells [1-3]. It has been reported as an important regulator of B lymphocyte development and growth $[4,5]$, being involved in key aspects of the pathogenesis of diffuse large B cell lymphoma, the most common form of highgrade human lymphoma [2, 5]. Although its biological mechanism of action remains mostly unclear, it was suggested that BCL- 6 deregulation might lead cells to become unresponsive to anti-proliferative signals through functional inactivation of p53 tumour suppressor gene and altered apoptosis in response to DNA damage [6-8].

\section{KARGER \\ Fax +4161306 1234 \\ E-Mail karger@karger.ch}

www.karger.com (c) $2009 \mathrm{~S}$. Karger AG, Basel

$1015-2008 / 09 / 0765-0235 \$ 26.00 / 0$

Accessible online at:

www.karger.com/pat
António E. Pinto, MD

Serviço de Anatomia Patológica, Instituto Português Oncologia de Lisboa, E.P.E. Rua Prof. Lima Basto

PT-1099-023 Lisboa (Portugal)

Tel./Fax +351 21722 9825, E-Mail aepinto@ipolisboa.min-saude.pt 
Recently, Bos et al. [9] showed that, outside the lymphoid system, BCL-6 oncoprotein was also expressed in invasive breast cancer, being associated with cyclin D1 activation and hypoxia-inducible factor- $1 \alpha$. Since several studies have pointed to BCL-6 protein expression as a putative prognostic factor in non-Hodgkin's lymphoma [10-12], we hypothesize whether a similar finding could occur in breast carcinoma.

The aim of this study was to investigate BCL- 6 expression in primary breast carcinoma and corresponding tumour recurrences and metastases, using immunohistochemistry (IHC) and real-time polymerase chain reaction (RT-PCR) techniques, in an attempt to understand the biological role of BCL- 6 in breast cancer disease progression.

\section{Subjects and Methods}

\section{Clinicopathological Data}

The series investigated consisted originally of 100 consecutive patients with primary invasive ductal breast carcinoma diagnosed and treated at our institution between January 1994 and May 1995. Informed consent was obtained from every patient enrolled in this study. Seven cases, however, lacked available tumour sampling material and were excluded from the study. The mean age of the patients was 59 years (interval range: 23-87). Histological type and pathological stage (stage $\mathrm{I}=21,22.6 \%$; stage IIA $=33,35.5 \%$; stage IIB $=35,37.6 \%$; stage IIIA $=4,4.3 \%$ ) were evaluated according to TNM-UICC classification [13]. Tumour grade of differentiation was assessed following the Elston and Ellis grading system [14].

Surgical resection was the primary treatment, including 71 radical modified mastectomies and 22 tumorectomies. Axillary dissection was carried out in all patients, with further histological study of at least 10 lymph nodes. No patient was submitted to neoadjuvant therapy. As adjuvant treatment, the patients underwent radiotherapy $(n=60)$, hormonal therapy $(n=42)$ and chemotherapy $(\mathrm{n}=48)$.

Follow-up information was assessed by review of clinical records. Complete data was available for every patient in the series. The median follow-up time was 120 months (interval range: 98140). The study's end-points were disease-free survival (time elapsed between diagnosis and the first disease recurrence) and overall survival (interval between diagnosis and the last clinical observation of the disease or death). At the end of the follow-up period, 50 patients (53.8\%) were alive without evidence of disease, 3 (3.2\%) were alive with disease, $34(36.6 \%)$ had died of disease (median follow-up 48 months, range: 2-125), 41 (44.1\%) had shown disease recurrences and $6(6.4 \%)$ had died of other causes.

\section{Immunohistochemistry}

IHC of BCL-6 oncoprotein was performed on formalin-fixed paraffin-embedded sections, which were attached to capillary gap microscope slides (S2024; Dako, Glostrup, Denmark). The sections were dried at $60^{\circ} \mathrm{C}$ overnight and dewaxed routinely. The antigen retrieval was carried out using a stainless-steel 6-liter capacity pressure cooker, with $0.01 \mathrm{M}$ sodium citrate buffer, $\mathrm{pH} 6.0$ for 6 min. The primary monoclonal antibody (M7211; Dako) was used at 1:10 dilution for $60 \mathrm{~min}$. Immunohistochemical detection was automatically performed using a Techmate 500 instrument (Dako). Bound antibody was detected using a ready-to-use streptavidin conjugated to horseradish peroxidase, and visualised using a solution containing 3,3'-diaminobenzidine tetrahydrochloride (5001; Dako). The sections were counterstained with Mayer's haematoxylin. As positive control, a sample of tonsil was used. For negative control the primary antibody was omitted in the IHC assay.

Nuclear specific staining was evaluated semi-quantitatively by 2 investigators using a 2-headed microscope. BCL-6 immunoreactivity was analysed by counting at least 500 tumour cells, and the results were recorded as the percentage of positively stained malignant cells: 0 (negative), $1+(<10 \%), 2+(\geq 10$ and $<50 \%)$ and $3+(\geq 50 \%)$. Specimens showing more than $10 \%$ stained nuclei were considered positive.

The immunohistochemical expression of oestrogen (ER) and progesterone receptors was determined on paraffin blocks using the streptavidin-biotin complex peroxidase technique (NCL-ER receptor $6 \mathrm{~F} 11$ and NCL-progesterone primary monoclonal antibodies; Novocastra Laboratories, Newcastle, UK), as previously described [15]. A 10\% cut-off level was used for discriminating positive versus negative cases.

\section{DNA Flow Cytometry}

Flow-cytometric analysis was performed on representative frozen samples of tumour tissue obtained at surgical resection, according to a previously reported procedure [15]. Samples were treated with Nonidet P40 non-ionic detergent (Sigma, St. Louis, Mo., USA) for cell lysis, and nuclei were stained with a propidium iodide solution (Sigma), including ribonuclease for digestion of double-stranded RNA. Fluorescent microbeads (DNA-Check; Coulter, Hialeah, Fla., USA) were used for daily calibration of the Epics Profile II flow cytometer (Coulter Electronics). Cell cycle analysis of DNA histograms were performed using the Multicycle program (Phoenix Flow Systems, San Diego, Calif., USA), with histograms being rejected with coefficient of variation $>6 \%$ and/ or background debris $>20 \%$. The tumours were classified as diploid or aneuploid according to DNA ploidy pattern. Mixed nonmalignant diploid cells in the same sample analysed were used as internal reference standard.

\section{Breast Cancer Cell Lines}

The following breast cancer cell lines were used for functional studies and also for studying the regulation of BCL-6: T47D (nonmetastatic, ER positive); MCF-7 (non-metastatic, ER positive); ZR75.1 (non-metastatic, ER positive); MDA-MB435 (metastatic, ER negative).

\section{RNA Extraction, cDNA Synthesis and Real-Time PCR}

Cells and tissues were lysed in appropriate buffers after deparaffination of the embedded material at $65^{\circ} \mathrm{C}$. Total cellular RNA, extracted with Trizol (Invitrogen, Carlsbad, Calif., USA), cDNA synthesis and RT-PCR (semi-quantitative, using SYBRgreen; Applied Biosystems, Foster City, Calif., USA) were performed following conventional protocols. mRNA quantification 
Table 1. Immunohistochemical BCL-6 expression in available breast cancer recurrence cases

\begin{tabular}{rlll}
\hline Case & Primary tumour & Local recurrence & $\begin{array}{l}\text { Distant } \\
\text { metastasis }\end{array}$ \\
\hline 6 & positive (2+) & positive (2+) & negative \\
9 & positive (2+) & positive (2+) & negative \\
11 & negative & positive (2+) & negative \\
38 & positive (3+) & & negative \\
44 & negative & negative & \\
45 & positive (3+) & negative & \\
74 & negative & negative &
\end{tabular}

Note that in case 6, two tumour recurrent samples were evaluated (1 local recurrence plus 1 distant metastasis).

was done using the ABI Prism 7700 Sequence Detection System and the SYBR Green Master Mix kit (both from Applied Biosystems). The $18 \mathrm{~S}$ gene was used as standard reference (normalizer).

Beyond BCL-6, other metastasis-related genes, namely, CXCchemokine receptor 4 (CXCR4), fms-like tyrosine kinase-1 (FLT1) and integrin $\beta-3$ (Itg $\beta-3)$, were investigated. Primers and probes were designed using the Primer Express TM 1.0 program (Applied Biosystems). The primer sequences were as follows: BCL-6 F (forward): GCC GGC TGA CAG CTG TAT C, BCL-6 R (reverse): CGG AGA CGA TTA AGG TTG AGA AG; CXCR4 F: CAG TGG CCG ACC TCC TCT T, CXCR4 R: CAG TTT GCC ACG GCA TCA; FLT-1 F: TCG CCG GAA GTT GTA TGG TT, FLT-1 R: GAT AAT TAA CGA GTA GCC ACG AGT CA; Itg $\beta$-3 F: CTC GAA AAC CCC TGC TAT GAT ATG, Itgß-3 R: TTA GCG TCA GCA CGT GTT TGT.

To study the importance of overexpressing BCL-6, full-length BCL-6 was cloned and inserted into a pOPRSVI/MCS Vector (kind gift from Prof. M. Sato, Osaka, Japan). This construct was used to transfect the different cell lines, using oligofectamine (Clontech, Palo Alto, Calif., USA), and following conventional protocols.

To determine the methylation status of BCL- 6 in different cell lines, 5-azacytidine (at 5 and $10 \mu \mathrm{M}$ ) was used as a demethylation agent; treated cells were subsequently analysed for BCL- 6 expression following RNA extraction, cDNA synthesis and RT-PCR, as described above.

\section{Statistical Analysis}

The correlations between BCL- 6 expression and other variables were assessed using the $\chi^{2}$ test. To compare the means of 2 samples on functional assays study by PCR technique (fig. 3-5), the Student's t test was used; each experiment was performed twice with experimental triplicates. Cumulative survival probabilities were evaluated by the Kaplan-Meier method, and the differences between survival curves were analysed by the log-rank test. The prognostic role of the different factors on patient's survival was evaluated by fitting a multivariate Cox regression model. Significance was reached if $\mathrm{p}<0.05$ for the statistical method used.
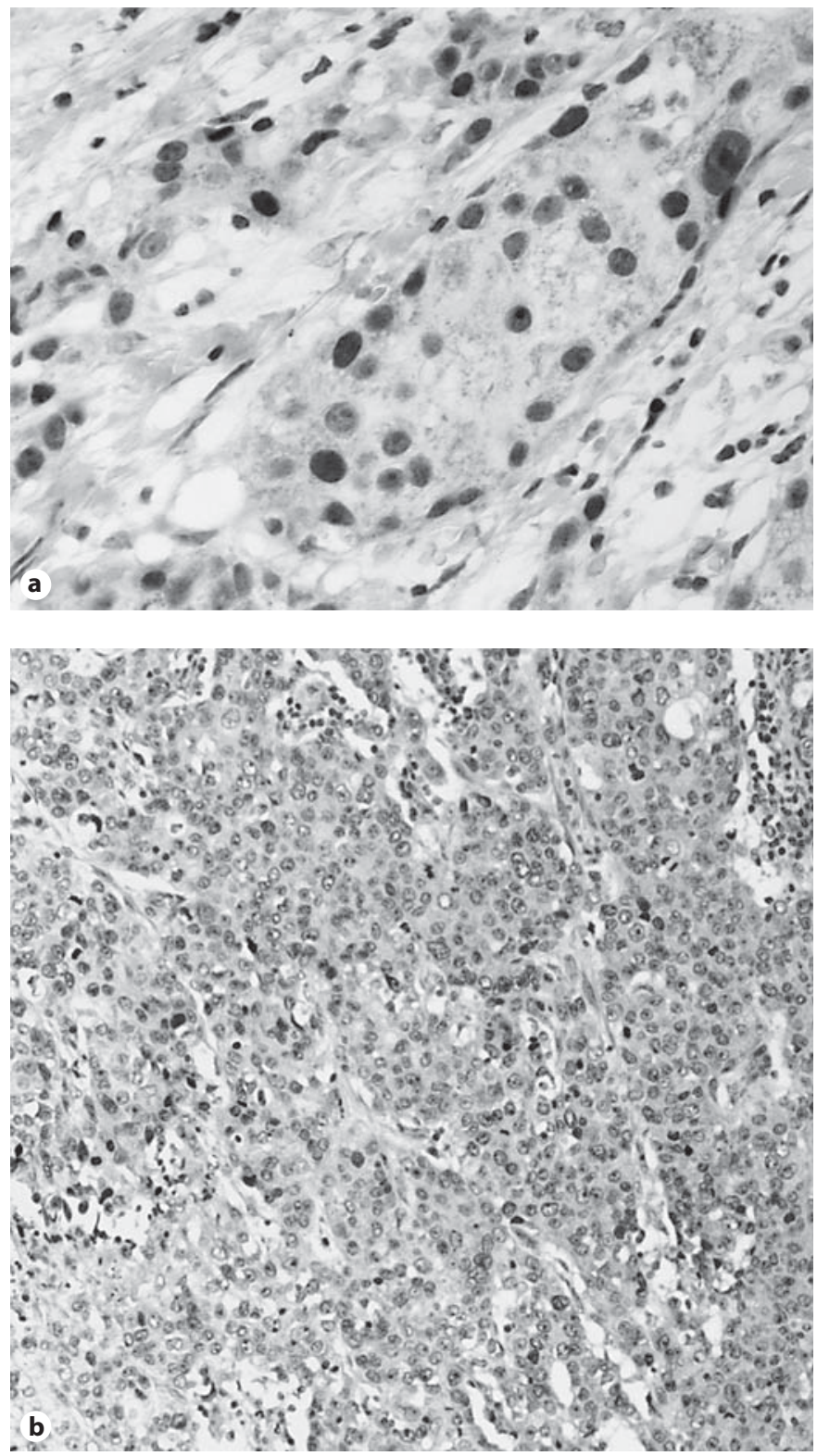

Fig. 1. a An immunohistochemically BCL-6-positive primary breast carcinoma. $\times 400$. b Its corresponding metastatic axillary lymph node which lacked BCL- 6 expression. $\times 100$.

\section{Results}

\section{IHC Study}

Immunohistochemical BCL-6 oncoprotein expression was positive in $22(23.7 \%)$ cases (7 IHC $2+$ plus 15 IHC $3+$ ) and negative in 71 (76.3\%) cases (including 13 IHC 1+) of the whole series. It was also assessed in the metastatic axillary lymph nodes of $\mathrm{pN} 1$ breast cancer patients. All 47 metastatic nodes lacked BCL-6 expression, 


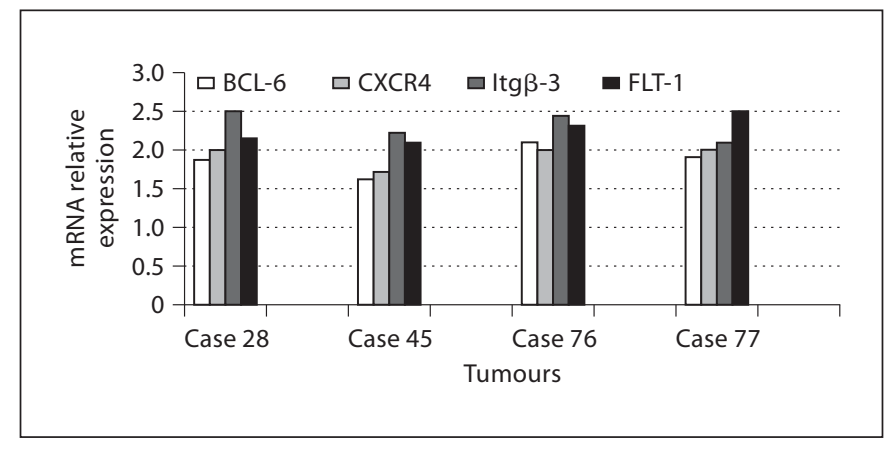

Fig. 2. Co-expression of the 4 genes in 4 of 17 breast cancer cases assessed for BCL-6, CXCR4, Itg $\beta-3$ and FLT-1 gene expression using RT-PCR.

Table 2. Correlation of BCL- 6 oncoprotein expression with pathological and cytometric parameters

\begin{tabular}{|c|c|c|c|c|}
\hline \multirow[t]{2}{*}{ Variables } & \multirow[t]{2}{*}{$\mathrm{n}$} & \multicolumn{2}{|l|}{ BCL-6 } & \multirow[t]{2}{*}{$\mathrm{p}$ value } \\
\hline & & $\%$ negative & $\%$ positive & \\
\hline \multicolumn{4}{|l|}{ Tumour size } & 0.710 \\
\hline pT1 & 31 & 80.6 & 19.4 & \\
\hline pT2 & 56 & 75.0 & 25.0 & \\
\hline pT3 & 6 & 66.7 & 33.3 & \\
\hline \multicolumn{4}{|c|}{ Lymph node status } & 0.852 \\
\hline $\mathrm{pN} 0$ & 46 & 78.3 & 21.7 & \\
\hline $\mathrm{pN} 1$ & 47 & 74.5 & 25.5 & \\
\hline \multicolumn{4}{|c|}{ Histological grade } & 0.898 \\
\hline G1 & 18 & 77.8 & 22.2 & \\
\hline G2 & 26 & 73.1 & 26.9 & \\
\hline G3 & 49 & 77.6 & 22.4 & \\
\hline \multicolumn{4}{|l|}{ DNA ploidy } & 0.617 \\
\hline Diploid & 36 & 80.6 & 19.4 & \\
\hline Aneuploid & 57 & 73.7 & 26.3 & \\
\hline \multicolumn{4}{|c|}{ Oestrogen receptors } & 0.633 \\
\hline Positive & 61 & 78.7 & 21.3 & \\
\hline Negative & 32 & 71.9 & 28.1 & \\
\hline \multicolumn{4}{|c|}{ Progesterone receptors } & 0.500 \\
\hline Positive & 46 & 80.4 & 19.6 & \\
\hline Negative & 47 & 72.3 & 27.7 & \\
\hline
\end{tabular}

p value: $\chi^{2}$ test.

even when the corresponding primary breast carcinomas showed BCL- 6 positivity (12 of 47 cases; $\mathrm{p}<0.001$; fig. 1 ). In this series, we further investigated available archival specimens of 9 breast cancer cases that had recurred (table 1): all tumour samples showed similar or decreased BCL- 6 expression compared with primary tumours.
Although gradually higher percentage of BCL-6-positive expression was observed in more advanced stages of disease (great size node-positive aneuploid tumours lacking hormone receptors), there was no statistically significant correlation of BCL- 6 oncoprotein with the pathological and cytometric parameters evaluated (table 2). Similarly, when the covariable age of patients was categorized ( $\leq 50$ vs. $>50$ years), no significant association was found between the latter and BCL- 6 expression ( $\mathrm{p}=$ $0.201)$.

\section{RT-PCR in vivo Analyses}

In a representative subset of 17 breast cancer patients (8 BCL-6 IHC positive and 9 BCL-6 IHC negative, with and without favourable clinical outcome; 4 vs. 4 cases and 5 vs. 4 cases, respectively), we further assessed BCL- 6 and the other metastasis-related genes in primary tumours using RT-PCR. All but 1 tumour for BCL-6, all tumours for CXCR4, 6 of 17 tumours for Itg $\beta-3$ and 5 of 17 tumours for FLT-1 showed gene expression. Co-expression of the 4 genes was found in 4 of 17 cases (fig. 2), but lacking correlation with clinical outcome $(\mathrm{p}=0.661)$. No significant associations were found between both $\operatorname{Itg} \beta-3$ and FLT-1 gene expression and survival $(\mathrm{p}=0.363$ and $\mathrm{p}=0.742$, respectively), as well as between the immunohistochemical oncoprotein expression and the molecular genetic analysis of BCL-6. The only statistically significant associations found in RT-PCR in vivo study were between BCL- 6 and CXCR4 gene expression $(\mathrm{p}=0.036)$ and Itg $\beta-3$ and FLT-1 gene expression $(\mathrm{p}=0.053)$.

\section{Functional Assays Study}

Molecular and cellular (functional assay) approaches were used to study the regulation of BCL- 6 expression and its putative function(s) on breast cancer cells.

First, when comparing a primary tumour with the corresponding metastasis, the results obtained showed that the absence of protein (immunohistochemical) staining described above correlates with the absence of RNA for BCL-6 (fig. 3), as determined by semi-quantitative PCR.

Next, to try and understand why BCL- 6 expression decreases significantly in metastasis, the hypothesis that methylation of the BCL- 6 promoter might be involved in this 'silencing' process was tested. In fact, treatment of BCL-6-expressing breast cancer cell lines with 5-azacytidine results in a significant decrease in the levels of BCL6 RNA (as determined by RQ-PCR; fig. 4), which strongly suggests that its promoter may be demethylated in breast cancer metastasis. 


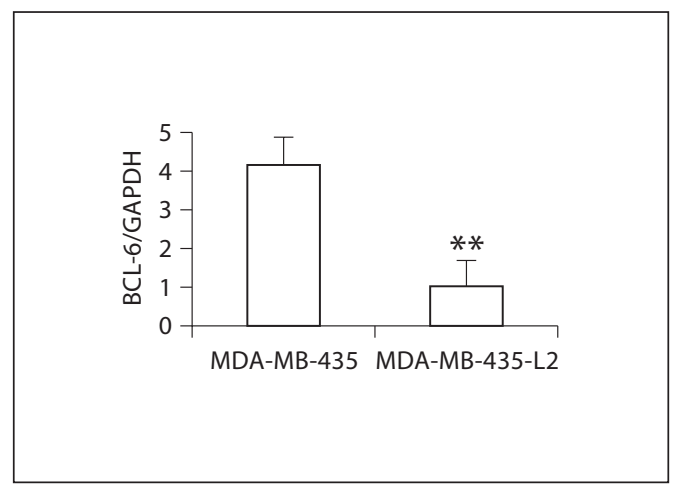

Fig. 3. BCL- 6 expression in a breast cancer cell line and its derived metastasis (RT-PCR). The M435 breast cancer cell line is an ERnegative cell line that metastasises in vivo; BCL- 6 expression is significantly reduced in its derived metastases $\left({ }^{* *} \mathrm{p}<0.05\right)$.

Finally, to investigate how BCL-6 might affect cell properties involved in cell movement and migration, the breast cancer cells with low or absent BCL- 6 expression were stably transfected. As shown in figure 5 , the levels of CXCR4, FLT-1 and Itg $\beta-3$ significantly increased in the transfected clones, suggesting that BCL- 6 might control (directly or indirectly) the expression of these metastasis-related genes.

\section{Prognostic Study}

Kaplan-Meier analysis showed no significant differences between survival curves according to BCL- 6 expression (fig. 6). In addition, the Cox regression univariate model for patient's survival, including all prognostic parameters investigated, revealed that BCL- 6 expression has no statistically significant influence on clinical outcome (table 3), even when other cut-off points were used (such as adding the BCL-6 IHC $1+$ to the other positive cases; data not shown). Further multivariate Cox analysis showed that, first of all, axillary lymph node status and, secondarily, histological grade and progesterone receptors are independent prognostic factors in breast cancer (table 4).

\section{Discussion}

The published literature on BCL- 6 expression outside the context of lymphoid system is very scarce $[9,16]$, making the inter-laboratory comparison of data difficult. We found BCL- 6 immunoexpression in 22 of 93 (23.7\%) primary breast carcinomas. Using the same cut-off value

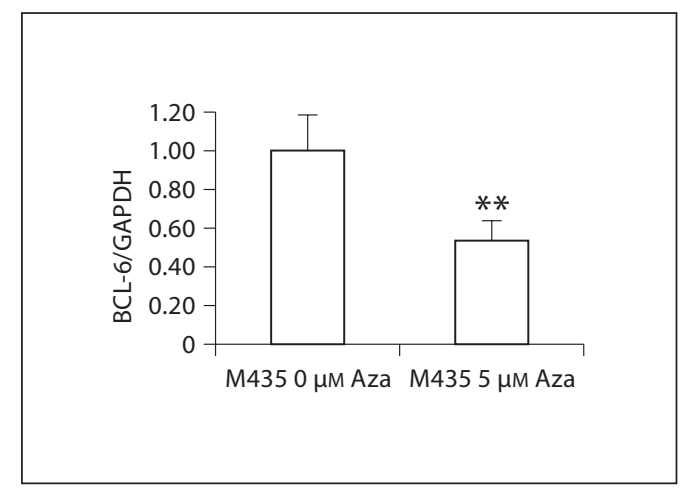

Fig. 4. BCL-6 expression may be regulated by methylation (RTPCR). 5-Azacytidine (5-Aza) is a demethylation agent; treatment of M435 breast cancer cell line with 5-Aza significantly reduces BCL- 6 expression $\left({ }^{* *} \mathrm{p}<0.05\right)$.

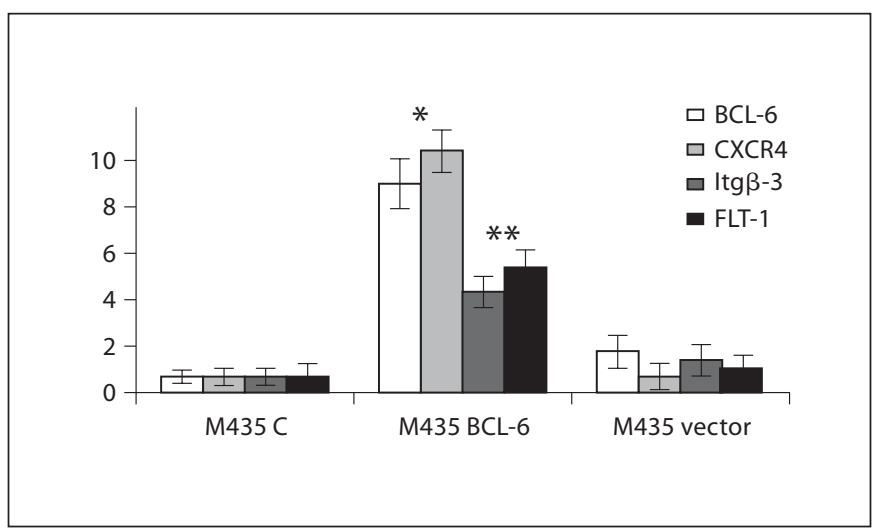

Fig. 5. RT-PCR analysis of genes involved in cell movement and migration. As shown, BCL-6-transfected breast cancer cell lines express significantly higher levels of CXCR4 $\left({ }^{*} \mathrm{p}<0.01\right), \operatorname{Itg} \beta-3$ $\left({ }^{* *} \mathrm{p}<0.05\right)$ and FLT-1 $\left({ }^{* *} \mathrm{p}<0.05\right)$.

( $\geq 10 \%$ ) for discriminating positivity, Bos et al. [9] reported BCL- 6 overexpression in 24 of 150 (16\%) breast cancers. In our study, although higher BCL-6-positive expression has shown a trend to be associated with adverse characteristics of the tumours and advanced stages of disease, this did not reach statistical significance (table 2). In addition, no significant correlation between BCL- 6 and tumour grade of differentiation was observed. Logarajah et al. [16] found that BCL-6 is expressed in $68 \%$ of histologically high-grade ductal breast carcinomas, different from our finding ( $\mathrm{G} 3=22.4 \%$ ); however, when they excluded weak immunostaining as being positive, like we did, that figure fell to $29.4 \%$. 

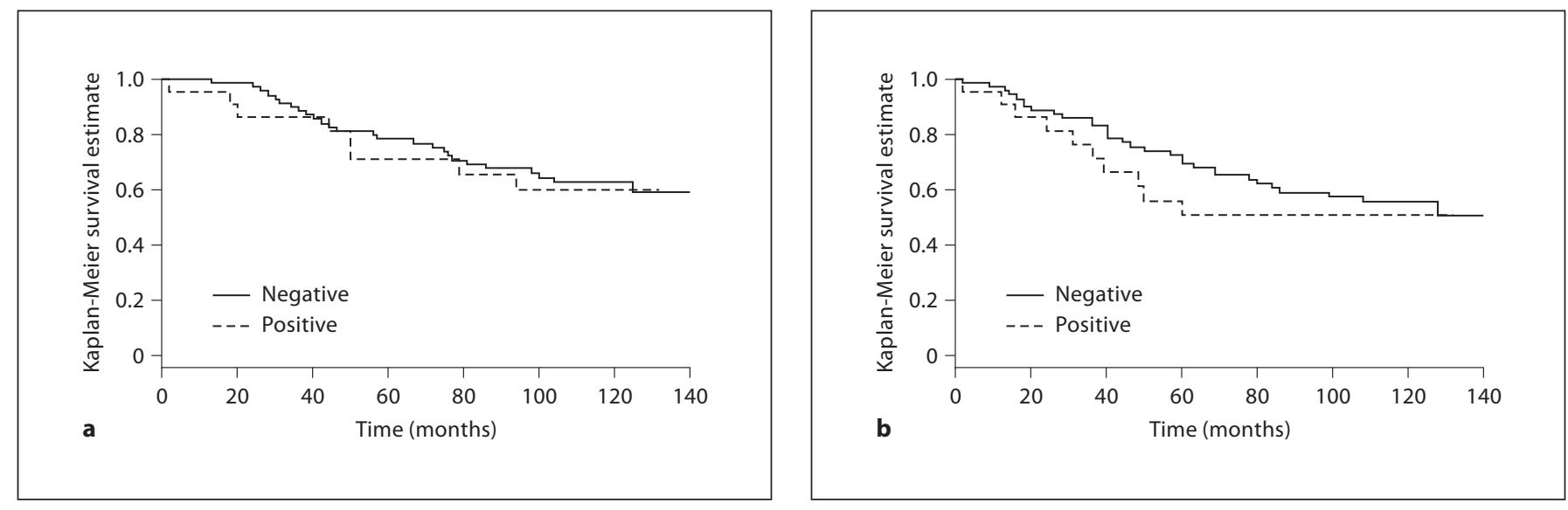

Fig. 6. There were no significant differences between Kaplan-Meier overall survival curves $(p=0.780 ; \mathbf{a})$ and disease-free survival curves $(\mathrm{p}=0.530 ; \mathbf{b})$ according to BCL- 6 expression.

Table 3. Cox regression univariate model for patients' survival

\begin{tabular}{llllllll}
\hline Variables & \multicolumn{2}{l}{ Overall survival } & & \multicolumn{3}{l}{ Disease-free survival } \\
\cline { 2 - 3 } \cline { 5 - 6 } & RR & $95 \% \mathrm{CI}$ & $\mathrm{p}$ & & $\mathrm{RR}$ & $95 \% \mathrm{CI}$ & $\mathrm{p}$ \\
\hline
\end{tabular}

$B C L-6$

$\begin{array}{lllllll}\text { Negative }^{1} & 1 & - & - & 1 & - & - \\ \text { Positive } & 1.12 & 0.51-2.47 & 0.780 & 1.25 & 0.61-2.56 & 0.530\end{array}$

Tumour size

$\begin{array}{lllllll}\text { pT1 }^{1} & 1 & - & - & 1 & - & - \\ \text { pT2 } & 1.20 & 0.56-2.58 & 0.640 & 1.40 & 0.69-2.86 & 0.350 \\ \text { pT3 } & 3.94 & 1.34-11.60 & 0.013 & 4.89 & 1.79-13.39 & 0.002\end{array}$

\begin{tabular}{lllllll}
\hline \multicolumn{2}{l}{$\begin{array}{l}\text { Lymph node status } \\
\text { pN0 }^{1}\end{array} 1$} & - & - & 1 & - & \\
pN1 & 3.15 & $1.50-6.61$ & 0.002 & 2.99 & $1.55-5.79$ & 0.001 \\
\hline
\end{tabular}

\begin{tabular}{|c|c|c|c|c|c|c|}
\hline \multicolumn{7}{|c|}{ Histological grade } \\
\hline $\mathrm{G} 1^{1}$ & 1 & - & - & 1 & - & - \\
\hline G2 & 4.35 & $0.96-19.7$ & 0.056 & 3.47 & $0.98-12.3$ & 0.05 \\
\hline G3 & 4.83 & $1.13-20.6$ & 0.033 & 4.46 & $1.35-14.8$ & 0.014 \\
\hline
\end{tabular}

\begin{tabular}{lllllll}
\hline DNA ploidy & & & & & & \\
Diploid $^{1}$ & 1 & - & - & 1 & - & - \\
Aneuploid & 2.17 & $1.01-4.66$ & 0.047 & 1.88 & $0.96-3.70$ & 0.066
\end{tabular}

ER

\begin{tabular}{lllllll} 
Positive $^{1}$ & 1 & - & - & 1 & - & - \\
Negative & 1.54 & $0.77-3.04$ & 0.220 & 1.52 & $0.81-2.82$ & 0.190 \\
\hline
\end{tabular}

PGR

$\begin{array}{lllllll}\text { Positive }^{1} & 1 & - & - & 1 & - & - \\ \text { Negative } & 1.80 & 0.90-3.59 & 0.097 & 1.96 & 1.04-3.7 & 0.038\end{array}$ test.

$\mathrm{RR}=$ Relative risk; $\mathrm{CI}=$ confidence interval. $\mathrm{p}$ value: Wald

${ }^{1}$ Reference category.
In our study, the assessment of BCL- 6 and other metastasis-related genes in a representative subset of breast cancer patients, using RT-PCR, showed a discrepancy between BCL- 6 gene expression measured at the mRNA level and the corresponding immunohistochemical protein expression. This is not uncommon and may be explained by several post-transcriptional mechanisms, including protein translation, post-translation modification and degradation, which may influence the level of the oncoprotein present in tumour cells $[17,18]$.

The most intriguing finding in our study was the lack of BCL-6 immunoexpression in all metastatic axillary lymph nodes, despite the presence of BCL-6 positivity in some of the corresponding primary breast carcinomas (12 of 47 cases). The loss of BCL- 6 expression with disease progression was strongly corroborated by the observation of similar or reduced BCL- 6 immunoexpression in all cases of disease recurrence compared with primary tumours (table 1).

Epigenetic regulation of gene expression has been extensively studied in breast cancer, in particular during metastasis formation. In detail, several studies demonstrated that in breast cancers there is generally a hypermethylation pattern, namely of genes including p16, ER $\alpha$ and MGMT (methyl transferases) among other genes involved in DNA repair, cellular immortalization and hormonal regulation [19]. Another study [20] suggested that a hypermethylation profile (in specific genes) of primary breast cancer may be associated with sentinel lymph node metastasis; in this latter study, particular relevance was attributed to $\mathrm{CDH} 1$, as a key tumour suppressor gene and 
Table 4. Cox regression multivariate analysis for patients' survival

\begin{tabular}{|c|c|c|c|c|c|c|}
\hline \multirow[t]{2}{*}{ Variables } & \multicolumn{3}{|c|}{ Overall survival } & \multicolumn{3}{|c|}{ Disease-free survival } \\
\hline & $\mathrm{RR}$ & $95 \% \mathrm{CI}$ & $\mathrm{p}$ & $\mathrm{RR}$ & $95 \%$ CI & $\mathrm{p}$ \\
\hline \multicolumn{7}{|c|}{ Lymph node status } \\
\hline $\mathrm{pN} 0^{1}$ & 1 & - & - & 1 & - & - \\
\hline $\mathrm{pN} 1$ & 3.37 & $1.60-7.09$ & 0.001 & 3.67 & $1.86-7.22$ & $<0.001$ \\
\hline \multicolumn{7}{|c|}{ Histological grade } \\
\hline $\mathrm{G} 1^{1}$ & 1 & - & - & 1 & - & - \\
\hline G2 & 4.34 & $0.96-19.6$ & 0.056 & 4.39 & $1.21-15.9$ & 0.024 \\
\hline G3 & 5.43 & $1.27-23.2$ & 0.022 & 4.35 & $1.30-14.6$ & 0.017 \\
\hline \multicolumn{7}{|l|}{ PGR } \\
\hline Positive $^{1}$ & & & & 1 & - & - \\
\hline Negative & & & & 2.09 & $1.02-4.29$ & 0.045 \\
\hline
\end{tabular}
test.

$\mathrm{RR}=$ Relative risk; $\mathrm{CI}=$ confidence interval. $\mathrm{p}$ value: Wald

${ }^{1}$ Reference category.

putative 'metastasis gene'. Others [21] also suggested that there may be a very high frequency of hypermethylated genes in breast cancer metastasis to specific organs, including bone, brain and lung.

To confirm and possibly explain the previous IHC data, we further used a molecular analysis approach. Although both techniques yielded similar BCL-6-decreasing results in breast cancer metastases (fig. 3), our findings on the regulation of BCL- 6 expression by methylation appear somewhat surprising, since no association between the age of patients and BCL-6 was observed, and, in addition, we clearly showed that demethylating agents (such as 5-azacytidine) cause a significantly reduction in BCL-6. This might be explained by an indirect effect (that is, regulating the methylation status of their promoters) in a partner gene (or genes), that may control BCL- 6 expression. The putative partner genes that control BCL- 6 expression on primary breast cancer and their related metastases are still undisclosed.

In view of the latter, another apparently contradictory finding was the identification of BCL- 6 target genes that may correlate with a more aggressive (metastatic) phenotype of primary breast cancer cells. In stable transfectants for BCL-6, the levels of genes such as CXCR4 (a chemokine receptor previously described to identify metastatic breast cancer cells) [22], Itg $\beta-3$ and FLT-1 increase significantly compared to their untransfected counterparts (fig. 5). FLT-1 (a vascular endothelial growth factor receptor) was recently described to play a key role in regu- lating the proliferation of subsets of breast cancers [23]. In turn, the role of $\operatorname{Itg} \beta-3$ was recognised in the context of prostate cancer metastasis, where a link between chemokine receptor expression and integrin-triggered tumour dissemination was suggested [24]. In our study, however, the co-expression of the 4 genes was observed in only 4 of 17 breast cancer cases investigated, and was not statistically associated with patients' survival.

Taken together, our preliminary experiments raised more questions than answers, since it is difficult to reconcile the lack of BCL-6 expression in metastatic lymph nodes with the identification of some of the genes possibly involved in breast cancer cell movement and migration. However, in our in vivo analyses of a small subset of patients, we did not prove the prognostic value of these metastasis-related genes. The link with BCL- 6 remains largely unknown and will be the subject of future studies.

To our knowledge, the present work is the first attempt to investigate the potential prognostic significance of BCL- 6 in relation to other standard factors in breast cancer. The hypothesis was raised because the significant correlation between the oncoprotein expression and clinical outcome in non-Hodgkin's lymphoma has been previously reported [10-12]. However, using a Cox regression model, we failed to demonstrate the prognostic impact of BCL- 6 oncoprotein on breast cancer patients' survival (tables 3 and 4 ).

In conclusion, the present results, confirmed by 2 techniques, IHC and RT-PCR, strongly suggest the loss of BCL- 6 expression in breast cancer disease progression, which may be explained by methylation status alterations of still unknown partner gene(s). In addition, the prognostic significance of BCL-6 oncoprotein expression in breast cancer is not proved.

\section{Acknowledgements}

The authors thank Teresa Ferreira and Teresa Pereira for their excellent technical work in IHC assays. 


\section{References}

$>1$ Ye BH, Rao PH, Chaganti RS, Dalla-Favera $\mathrm{R}$ : Cloning of bcl-6, the locus involved in chromosome translocations affecting band 3 q27 in B-cell lymphoma. Cancer Res 1993; 53:2732-2735.

-2 Ye BH, Lista F, LoCoco F, Knowles DM, Offit K, Chaganti RS, Dalla-Favera R: Alterations of a zinc finger-encoding gene, BCL- 6 , in diffuse large-cell lymphoma. Science 1993; 262:747-750.

3 Cattoretti G, Chang CC, Cechova K, Zhang J, Ye BH, Falini B, Louie DC, Offit K, Chaganti RS, Dalla-Favera R: BCL-6 protein is expressed in germinal-center B cells. Blood 1995;86:45-53.

$>4$ Wagner SD, Kaeda JS: BCL-6: rearrangement and mutation in lymphoma. Methods Mol Med 2005;115:251-270.

5 Pasqualluci L, Bereschenko O, Niu H, Klein U, Basso K, Guglielmino R, Cattoretti G, Dalla-Favera R: Molecular pathogenesis of non-Hodgkin's lymphoma: the role of Bcl-6. Leuk Lymphoma 2003;44(suppl 3):S5-S12.

6 Phan RT, Dalla-Favera R: The BCL-6 protooncogene suppresses p53 expression in germinal-centre B cells. Nature 2004;432:635639.

7 Phan RT, Saito M, Basso K, Niu H, Dalla-Favera R: BCL6 interacts with the transcription factor Miz-1 to suppress the cyclin-dependent kinase inhibitor p21 and cell cycle arrest in germinal center B cells. Nature Immunol 2005;6:1054-1060.

$>8$ Kusam S, Vasanwala FH, Dent AL: Transcriptional repressor BCL-6 immortalizes germinal center-like B cells in the absence of p53 function. Oncogene 2004;23:839-844.

$\checkmark 9$ Bos R, van Diest PJ, van der Groep P, Greijer AE, Hermsen MAJA, Heijnen I, Meijer GA, Baak JPA, Pinedo HM, van der Wall E, Shvarts A: Protein expression of B-cell lymphoma gene 6 (BCL-6) in invasive breast cancer is associated with cyclin $\mathrm{D}_{1}$ and hypoxia-inducible factor- $1 \alpha$ (HIF-1 $\alpha$ ). Oncogene 2003;22:8948-8961.
10 Winter JN, Weller EA, Horning SJ, Krajewska M, Variakojis D, Habermann TM, Fisher RI, Kurtin PJ, Macon WR, Chhanabhai M, Felgar RE, His ED, Medeiros LJ, Wieck JK, Reed JC, Gascoyne RD: Prognostic significance of Bcl- 6 protein expression in DLBCL treated with CHOP or R-CHOP: a prospective correlative study. Blood 2006;107:42074213.

11 Lossos IS, Jones CD, Warncke R, Natkunam Y, Kaizer H, Zehnder JL, Tibshirani R, Levy R: Expression of a single gene, BCL-6, strongly predicts survival in patients with diffuse large B-cell lymphoma. Blood 2001;98:945951.

12 Vitolo U, Botto B, Capello D, Vivenza D, Zagonel V, Gloghini A, Novero D, Parvis G, Calvi R, Ariatti C, Milan I, Bertini M, Boccomini C, Freilone R, Pregno P, Orsucci L, Palestro G, Saglio G, Carbone A, Gallo E, Guidano G: Point mutations of the BCL-6 gene: clinical and prognostic correlation in B-diffuse large cell lymphoma. Leukemia 2002;16:268-275.

13 Sobin LH, Wittekind CH (eds): UICC TNM Classification of Malignant Tumours, ed 6. New York, John Wiley and Sons, 2002.

14 Elston CW, Ellis IO: Pathological prognostic factors in breast cancer. I. The value of histological grade in breast cancer: experience from a large study with long-term follow-up. Histopathology 1991;19:403-410.

15 Pinto AE, André S, Soares J: Short term significance of DNA ploidy and cell proliferation in breast carcinoma: a multivariate analysis of prognostic markers in a series of 308 patients. J Clin Pathol 1999;52:604-611.

16 Logarajah S, Hunter P, Kraman M, Steele D, Lakhani S, Bobrow L, Venkitaraman A, Wagner S: BCL- 6 is expressed in breast cancer and prevents mammary epithelial differentiation. Oncogene 2003;22:5572-5578.
17 Gygi SP, Rochon Y, Franza BR, Aebersold R: Correlation between protein and mRNA abundance in yeast. Mol Cell Biol 1999;19: 1720-1730.

18 Celis JE, Kruhoffer M, Gromova I, Frederiksen C, Ostergaard M, Thykjaer T, Gromov P, Yu J, Palsdottir H, Magnusson N, Orntoft TF: Gene expression profiling: monitoring transcription and translation products using DNA microarrays and proteomics. FEBS Lett 2000;480:2-16.

19 Munot K, Bell SM, Lane S, Horgan K, Hanby AM, Speirs V: Pattern of expression of genes linked to epigenetic silencing in human breast cancer. Hum Pathol 2006;37:989999.

20 Shinozaki M, Hoon DS, Giuliano AE, Hansen NM, Wang HJ, Turner R, Taback B: Distinct hypermethylation profile of primary breast cancer is associated with sentinel lymph node metastasis. Clin Cancer Res 2005;11:2156-2162.

21 Mehrotra J, Vali M, McVeigh M, Kominsky SL, Fackler MJ, Lahti-Domenici J, Polyak K, Sacchi N, Garrett-Mayer E, Argani P, Sukumar S: Very high frequency of hypermethylated genes in breast cancer metastasis to bone, brain and lung. Clin Cancer Res 2004; 10:3104-3109.

22 Muller A, Homey B, Soto H, Ge N, Catron D, Buchanan ME, McClanahan T, Murphy E, Yuan W, Wagner SN, Barrera JL, Mohar A, Verastegui E, Zlotnik A: Involvement of chemokine receptors in breast cancer metastasis. Nature 2001;410:50-56.

23 Wu Y, Hooper AT, Zhong Z, Witte L, Bohlen P, Rafii S, Hicklin DJ: The vascular endothelial growth factor receptor (VEGFR-1) supports growth and survival of human breast carcinoma. Int J Cancer 2006;119:15191529.

24 Engl T, Relja B, Marian D, Blumenberg C, Muller I, Beecken WD, Jones J, Ringel EM, Bereiter-Hahn J, Jonas D, Blaheta RA: CXCR4 chemokine receptor mediates prostate tumor cell adhesion through $\alpha 5$ and $\beta 3$ integrins. Neoplasia 2006;8:290-301. 